Combustibles et de l'Energie, and the presentations were made by M. Ramonet, the then Minister of Industry and Commerce. The recipients were Dr. D. T. A. Townend, director-general of the British Coal Utilization Research Association; Prof. W. H. McAdams, Massachusetts Institute of Technology; M. G. Darrieus and Prof. G. Ribaud, members of the Academy of Sciences, Paris; Dr. F. Münzinger, German Federal Republic ; and Signor F. Squassi, presidente della Sezione Latium dell'Associazione Termotecnica Italiana.

\section{A Large Sunspot Group}

THE large sunspot group which has recently attracted some attention appeared around the Sun's limb in heliographic latitude $12^{\circ} \mathrm{N}$. on January 4 . It was carried across the disk by the Sun's rotation about its own axis, and disappears at the western limb on January 17. A close bipolar structure, the group has somewhat diminished in area since January 8 , when its area was 3,000 millionths of the Sun's visible hemisphere. It is, however, the largest group observed since May 1951 and, consequently, of the present sunspot cycle. Although there has been an unprecedented number of spots during the recent peak activity, no group has been observed approaching in size that seen in April 1947, the maximum area of which reached 6,100 millionths of the Sun's visible hemisphere and was the largest recorded since the Greenwich observations began in 1874. Adverse weather conditions at Herstmonceux have prevented continuous watch on this group, but so far (until January 11) no associated flare activity has been observed.

\section{Central Advisory Water Committee}

ThE Central Advisory Water Committee recently held its fourth meeting in London at the Ministry of Housing and Local Government, under the chairmanship of the Minister, Mr. Honry Brooke, when it received and adopted reports from two sub-committees set up in 1955 to inquire, respectively, into the growing demand for water and into the collection of information about water resources. Both reports will be published shortly.

The Committee requested the sub-committee on the demand for water to undertake a further inquiry, with extended terms of reference as follows: "In connexion with their investigations into the extent to which demands for water are increasing and the problems involved in meeting those demands, to inquire into the extent of uncontrolled abstractions of surface water for agriculture, especially irrigation, for industry and for other purposes, and into the effect of such abstractions on the quantity and quality of surface water available for all purposes ; to consider whether powers are needed to control such abstractions in general or in particular; and to make recommendations". Prof. J. Proudman was appointed chairman of the sub-committee in succession to Alderman Yates, who has resigned from the chairmanship owing to pressure of other work.

\section{Zoological Society of London : Young Zoologists Club}

Althougr the Zoological Society of London has been in existence for more than a hundred years, it has never had a junior section through which the great amount of scientific knowledge at its disposal could be made available to school-children. About a year ago it instituted, with the co-operation of the educational authorities of the Greater London area, regular lecture-demonstrations for school-children. The Society is now launching a Young Zoologists Club (XYZ Club) for children between the ages of eleven and eighteen. The Club will be based on the London Zoo. For 10s. a year (there are, as well, reduced subscription rates for schools, clubs and natural history societies) the membership includes the Club badge, free admission tickets (to the London Zoo, including the Aquarium and Children's Zoo, and Whipsnade Park), competitions with substantial cash prizes, meetings, an Information Bureau and, above all, the Zoo Magazine, which for the present is being published three times a year. Further information can be obtained from XYZ Club, The London Zoo, Regent's Park, London, N.W.1.

\section{Geochemistry}

As a means of making available to all interested jndividuals some of the current Russian research in geochemistry, the Geochemical Society of the United States has undertaken to publish an English translation of the Russian journal Geokhimiya, published by the Academy of Sciences of the U.S.S.R. The first number of this translation has now appeared (Geochemistry, No. 1, 1958. (A translation of the journal of the Academy of Sciences, U.S.S.R.) Pp. 1-130. Subseription (for eight issues) 20 dollars a year. Ann Arbor, Michigan: Geochemical Society, Prof. E. Wm. Heinrich, Mineralogical Laboratory, The University, 1958). It contains research papers dealing with the ionium method of determining the age of marine sediments, the formation of free hydrogen in the Earth's crust, X-ray investigations of natural oxides of uranium, paragenesis in boronbearing magnesium skarns, the evolution of rocks during progressive metamorphism, the distribution of cobalt, nickel and copper in hydrothermally altered rocks, experimental studies of the oxidation of eobalt and niekel arsenides in solutions containing oxygen and carbonic acid, rhenium in molybdenites, the zirconium/hafnium ratio in zircons, and a contribution to the geochemistry of titanium in intrusive processes of granitic series. The translation concludes with a brief description of the recent International Conference on Interplanetary Science.

\section{Symposium on Peptide Synthesis}

AN International Symposium was held in Prague during September 8-15, when chemists from many countries in Europe met, at the invitation of the Czechoslovak Academy of Science, to discuss the synthesis of peptides. The primary object of the symposium was to exchange experience in this field rather than to communicate new work (although several of the contributions included unpublished work), and as a basis for each section of the discussion reviews were contributed by Prof. T. Wieland (Frankfurt) on peptide bond formation based on carboxyl activation; Prof. S. Goldschmidt (Technische Hochschule, Munich) on peptide bond formation based on amino-group activation; Dr. G. T. Young (Oxford) on racemization in peptide synthesis; Dr. E. Wünsch (Max Planck Institut, Munich) on aminogroup protection; Prof. E. Tasehner (Danzig) on carboxyl group protection; Dr. J. Rudinger (Prague) on peptides of the diamino and dicarboxylic acids; Prof. M. Brenner (Basle) on peptides of the hydroxy. amino-acids; Dr. Young on peptides containing cysteine; Prof. M. M. Shemyakin (Moscow) on 